\title{
Nanoparticle Technology as a Double-Edged Sword: Cytotoxic, Genotoxic and Epigenetic Effects on Living Cells
}

\author{
Mytych Jennifer ${ }^{1,2}$, Wnuk Maciej ${ }^{1,2}$ \\ ${ }^{1}$ Department of Genetics, University of Rzeszow, Rzeszow, Poland; ${ }^{2}$ Centre of Applied Biotechnology and Basic Sciences, Univer- \\ sity of Rzeszow, Kolbuszowa, Poland. \\ Email: jennifermytych@wp.pl, mawnuk@gmail.com
}

Received October $20^{\text {th }}, 2012$; revised November $30^{\text {th }}, 2012$; accepted December $10^{\text {th }}, 2012$

\begin{abstract}
Nanoparticles are considered as powerful tools in nanotechnological applications. Due to their unique physicochemical properties, their interactions with different biological systems have been shown. Nanomaterials have been successfully used as coating materials or treatment and diagnosis tools. Nevertheless, toxic effects of nanoparticles in vitro and in vivo have also been reported. Here, we summarize the current state of knowledge on exposure routes, cellular uptake and toxicological activities of the commonly used nanoparticles. In this context, we discuss the mechanisms of toxicity of nanoparticles involving perturbation of redox milieu homeostasis and cellular signaling pathways.
\end{abstract}

Keywords: Nanoparticles; Nanotoxicology; Genotoxicity; Cytotoxicity; Epigenetics

\section{Introduction}

It is widely accepted that nanoparticles (NPs) and nanomaterials could be successfully used in food technology, cosmetics, modern chemistry and biomedicine. The attributes of organic and inorganic nanoparticles, such as small size, composition, surface structure, solubility, shape and aggregation allow for unlimited modifications of their basic properties such as diffusivity, targeting, stability, solubility, half-life in circulatory system and controlled drug release. Due to such unique features, nanoparticles have the advantage over traditional therapeutic and diagnostic agents [1-4]. Nanoresearch is focused on many life-sciences including applications in environmental, health and safety sciences.

Nevertheless, very little is known how NPs affect humans and the environment. Here, we resume current information on negative effects of NPs especially including their toxicity (Figure 1) [5-13].

\section{Exposure Routes, Cellular Uptake and Toxicological Effects}

The organism has several semi-open interfaces for exchange some substances with the environment. The same interfaces are the primary routes of exposure of nanoparticles such as inhalation, dermal absorption and ingestion.
Routes of NPs exposure is highly affected by a plethora of factors e.g. NPs stability in vivo and their toxicokinetics, absorption, distribution, conversion to more toxic metabolites, interaction with macromolecules [14].

The different compartments of the human respiratory track act as a nanoparticle filter. If a nanoparticle is very small $(<2.5 \mu \mathrm{m})$, it is very likely that it would reach the alveolar region. After absorption, nanoparticles can enter bone marrow, spleen or heart cells (through blood or lymph). Nanoparticles could associate, coagulate and in turn cause a disturbance of cardiac rhythm or nerve endings in the airway epithelia and the central nervous system [15]. Skin is the largest organ of the integumentary system consists of multiple layers of ectodermal tissue. Damaged skin is an ineffective particle barrier and even very small wound may accelerate nanoparticle uptake [16]. Chemical penetration into skin can occur through pilosebaceous or swat gland pores. Nanoparticle parameters important for overcoming the cell membrane barrier are: size, charge, shape, nanoparticle coating, hydrodynamic diameter, isoelectric point, $\mathrm{pH}$ gradient. For example, $\mathrm{TiO}_{2}, \mathrm{ZnO}(30-200 \mathrm{~nm})$ and nail-shaped NPs (39 - $45 \mathrm{~nm}$ ) can penetrate only the outer layer of the epidermis, while spherical Quantum dots (QDs) (15 - 45 $\mathrm{nm})$ are able to reach epidermis and even dermis [17]. In clinical studies, silver nanoparticles are used in coated dressings which are exerted in burnings treatment. Be- 


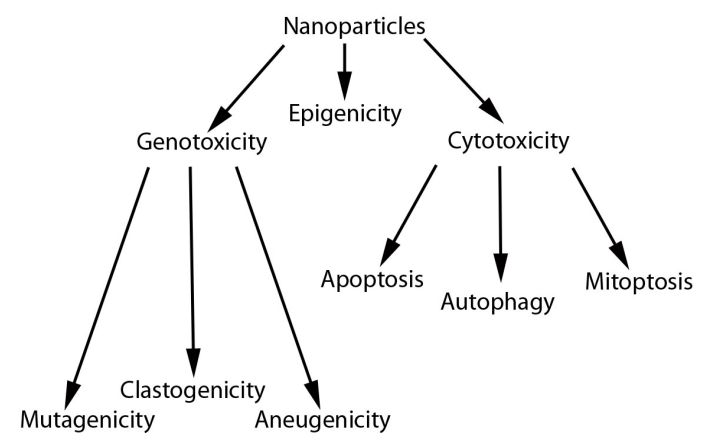

Figure 1. Potential toxic effects of nanoparticles on living cells.

sides good control of wound infection, they trigger abnormal elevations of blood silver levels and argyria as well. Nanoparticles can be also ingested directly in food, water and drugs. Nanocopper substances are several folds more toxic than copper. Nanocopper can also cause liver and kidney damage. After ingestion nanocopper particles react with hydrogen ions (gastric juice) and lead to a massive formation of bicarbonate ion. Alkalosis caused by overload of bicarbonate ions triggers hypopnea symptom and electrolyte disturbance [18]. Nanoparticles can enter the cell via diverse mechanisms such as simple diffusion across the cellular membrane, endocytosis, and phagocytosis or through ion canals or pores [19]. The key mechanisms of nanoparticle uptake include clathrinmediated endocytosis, caveolin-mediated endocytosis, macropinocytosis or phagocytosis. Clathrin-mediated endocytosis is involved in non-macrophage cell nanoparticle $(50-200 \mathrm{~nm})$ uptake and it leads to accumulation of extracellular macromolecules into clathrin-coated vesicles fused to early endosomal vesicles [20]. With endocytosis, particles are taken up via small pits in the membrane which is mediated by special receptors [21]. Macropinocytosis occurs from ruffled regions of the membrane within vacuoles $(\sim 0.5-5.0 \mu \mathrm{m})$ [22]. During phagocytosis, cell binds and internalizes particles bigger than $0.75 \mu \mathrm{m}$, and microglia are specialized in such uptake [23]. The same nanoparticle can be captured via various mechanisms. For example, diamond powder particle uptake is based on macropinocytosis or on clathrinmediated endocytosis pathways and uptake type affects intracellular metabolism [5]. Additionally, physicochemical parameters (coating, charge) of QDs may discriminate NPs uptake type [24]. After entering the cell, the same nanoparticle can cause different toxic effect which depends on cell type affected (Table 1). Several factors have been found to modulate NPs toxicity such as individual NPs physicochemical properties: size, charge, concentration, outer coating bioactivity (capping material, functional groups), and oxidative, photolytic, and mechanical stability $[25,26]$.

NPs can affect cytophysiology of the cell at different levels such as cellular, organelle level as well as at the level of genetic information which in turn may contribute to cytotoxicity, cancer development and aging [15,27]. NPs are so small that they can penetrate the small capillaries throughout the body and pass through biological membranes [28]. NPs $(<100 \mathrm{~nm})$ can enter the cell, NPs $(<40 \mathrm{~nm})$ can enter nucleus, and NPs $(<35 \mathrm{~nm})$ can pass the blood brain barrier. Moreover, it has been reported that metallic, metal oxide, semiconductor nanoparticles, polymeric nanoparticles and carbon based nanoparticles may cause cytotoxic effects, which is dose-, cell typeand treatment time-dependent [15,29]. NPs such as silver NPs $(15 \mathrm{~nm})$, molybdenum NPs $(30 \mathrm{~nm})$ and aluminum NPs $(30 \mathrm{~nm})$ were found to cause diverse effects on mouse type A spermatogonia. Molybdenum NPs at range of concentrations studied did not affect the cells, whilst silver NPs at concentration under $10 \mu \mathrm{g} / \mathrm{mL}$ induced dramatic changes such as cell clumping, precipitation, shrinkage and apoptosis. Aluminum nanoparticles did not cause any damage at concentrations below $10 \mu \mathrm{g} / \mathrm{mL}$ (formed aggregates, their effect on mitochondrial function could not be checked). Mitochondrial function and cell viability were reduced by silver NPs at the lowest concentration used and by molybdenum NPs at concentration of $50 \mu \mathrm{g} / \mathrm{mL}$. Silver NPs increased membrane leakage, whilst molybdenum NPs affected the membrane integrity at lower concentrations [30]. Additionally, cytotoxicity of gold NPs was reported to be associated with their size and not with ligand construction. Particles in the $1-2 \mathrm{~nm}$ size range are highly toxic, whereas smaller and bigger than that are not toxic and different cell death pathways (necrosis or apoptosis) are involved with different uptake kinetics or different targeting [31]. 24-h exposure to $\mathrm{ZnO}$ and $\mathrm{TiO}_{2}$ had a tremendous toxic impact on human skin fibroblast cells, while 4-h exposure caused only a mild adverse effect [29]. Besides cytoxicity, genotoxicity is another important factor in nanoparticle toxicity studies, especially for metal NPs, quantum dots and fullerenes (Table 1). Chromosomal fragmentation, point mutations, alterations in gene expression profiles, DNA strand breakages were also observed [15]. One of the assays used to assess the genotoxic potential of nanoparticles is the Ames Test. It was shown that $\mathrm{TiO}_{2}$ NPs and C-60 are able to induce deletion mutations in gpt $\Delta$ transgenic mutation assay system. $\mathrm{TiO}_{2}(5 \mathrm{~nm})$ caused a 2.2-fold increase in mutation yield in mouse embryonic fibroblast cells (MEF). At higher concentrations, $\mathrm{TiO}_{2}$ did not induce further increase in mutation yield. However, C-60 treatment stimulated dose-dependent induction of mutation in MEF cells [32]. Also, NPs can induce large chromosomal rearrangements such as aneuploidy [33].

As it has been already noticed, nanoparticle localization within the cell and interaction type with cellular 
Table 1. Selective toxicity of NPs.

\begin{tabular}{|c|c|c|c|}
\hline Selected nanoparticles & Cells & Physiological effect & Ref. \\
\hline \multirow{6}{*}{$\begin{array}{l}\text { Zinc oxide nanoparticles } \\
(\mathrm{ZnO})\end{array}$} & Hepatocytes & $\begin{array}{l}\text { Oxidative DNA damage and ROS-triggered mitochondria } \\
\text { mediated apoptosis }\end{array}$ & [73] \\
\hline & Renal cells & Nephrotoxicity and kidney metabolism alterations & [8] \\
\hline & Neurons & $\begin{array}{l}\text { Damage of the ionic homeostasis and the physiological functions } \\
\text { of neurons }\end{array}$ & [74] \\
\hline & Fetal lung fibroblasts & $\begin{array}{l}\text { Cellular mitochondrial dysfunction, morphological modifications } \\
\text { and apoptosis }\end{array}$ & [75] \\
\hline & Lymphocytes & Cytotoxicity and Cytokine Induction & [76] \\
\hline & Nasal mucosa cells & Cytotoxic, genotoxic and pro-inflammatory effects & {$[77]$} \\
\hline \multirow{5}{*}{$\begin{array}{l}\text { Carbon black nanoparticles } \\
\text { (CB-NPs) }\end{array}$} & Hepatocytes & Inflammatory and genotoxic effects & {$[56]$} \\
\hline & Renal cells & Cytotoxicity & {$[78]$} \\
\hline & Neurons & $\begin{array}{l}\text { Neurotoxic effect by disturbing the electrical activity of neuronal } \\
\text { networks }\end{array}$ & [7] \\
\hline & Lung epithelial cells & Cytotoxicity & [79] \\
\hline & Lymphocytes & Induction of chromosomal aberrations & {$[80]$} \\
\hline \multirow{5}{*}{ Silica nanoparticles $\left(\mathrm{SiO}_{2}\right)$} & Hepatocytes & Hepatotoxicity & [81] \\
\hline & Neurons & Dopaminergic neurons damage pathways & {$[82]$} \\
\hline & Lung epithelial cells & Toxicity and inflammatory response. & [83] \\
\hline & Lymphocytes & Cytotoxicity and genotoxicity & [84] \\
\hline & Fibroblast & Cytotoxicity & {$[25]$} \\
\hline \multirow{6}{*}{$\begin{array}{l}\text { Titanium dioxide } \\
\text { nanoparticles }\left(\mathrm{TiO}_{2}\right)\end{array}$} & Hepatocytes & Genotoxicity, carcinogenicity, hepatotoxicity and inflammation & {$[48,85]$} \\
\hline & Renal cells & Induction of oxidative stress and cytotoxicity & {$[86]$} \\
\hline & Neurons & Neurotoxicity & [7] \\
\hline & Lung epithelial cells & Genotoxicity, mutagenicity and carcinogenicity & {$[87,88]$} \\
\hline & Lymphocytes & $\begin{array}{l}\text { Induction of oxidative stress and reduction of immune capacity, } \\
\text { Genotoxicity }\end{array}$ & {$[27,80]$} \\
\hline & Bone-marrow cells & Genotoxicity, induction of oxidative stress, cytotoxicity & [89] \\
\hline \multirow{5}{*}{ Gold nanoparticles (AuNPs) } & Hepatocytes & Atrophy and necrosis & [90] \\
\hline & Myocardium cells & Cytotoxicity & [91] \\
\hline & Renal cells & Cytotoxicity & [92] \\
\hline & Lung fibroblast & Genotoxicity, autophagy & {$[12,93]$} \\
\hline & Bone-marrow cells & Cytotoxicity & [94] \\
\hline Quantum dots (QDs) & Lymphocytes & $\begin{array}{l}\text { Induction of DNA damage, formation of micronuclei (MNs), and } \\
\text { generation of DNA adduct (8-hydroxy-2-deoxyguanosine, } \\
\text { 8-OHdG) }\end{array}$ & [95] \\
\hline \multirow{2}{*}{ Fullerene C-60 } & Fibroblast & Lipid peroxidation and cytotoxicity & {$[40]$} \\
\hline & Lymphocytes & Genotoxicity & [96] \\
\hline \multirow{4}{*}{$\begin{array}{l}\text { Silver nanoparticles } \\
\text { (AgNPs) }\end{array}$} & Lung fibroblasts & $\begin{array}{l}\text { Cytotoxicity, increased production of ROS, DNA damage, } \\
\text { cell cycle arrest }\end{array}$ & {$[100]$} \\
\hline & Hepatocytes & $\begin{array}{l}\text { Cytotoxicity, induction of oxidative stress, decreased the activities } \\
\text { of superoxide dismutase and glutathione peroxides, DNA damage }\end{array}$ & [106] \\
\hline & Osteoblast & $\begin{array}{l}\text { Cytotoxicity, ROS generation, release of lactate } \\
\text { dehydrogenase, apoptosis }\end{array}$ & {$[107]$} \\
\hline & Bone-marrow cells & Cytotoxicity, genotoxicity, mutagenicity, carcinogenicity & {$[108]$} \\
\hline \multirow{2}{*}{$\begin{array}{l}\text { Super-paragnetic iron } \\
\text { oxide nanoparticle (SPION) }\end{array}$} & Renal cells & Genotoxicity, cytotoxicity, changed ROS properties & [109] \\
\hline & Fibroblasts & $\begin{array}{l}\text { Cytotoxicity, loss of adhesion skills, affected signaling } \\
\text { transduction pathway }\end{array}$ & {$[49,110]$} \\
\hline
\end{tabular}


components leading to cytotoxicity or genotoxicity depends on its size. Large particles can induce permanent damage to cell membrane via binding with cellular membrane proteins, whilst small particles can pass through membrane and harm organelles [34] and then, bigger ones can occur in the cytoplasm (mainly in vacuoles) and smaller ones in mitochondria. The interaction between QDs and human peripheral blood mononuclear cells are based on adsorption between amine groups within cell membrane and carboxyl group of QDs, and in some permeabilized cells, QDs distribution was observed only in the cytoplasm and in some other QDs were found even inside the nucleus and in the nucleolus. QDs which could not enter nuclear membrane is localized only inside cytosol membrane [35]. The same nanoparticles such as silica nanoparticles $\left(\mathrm{SiO}_{2}\right)$ with diverse type of energy transfer cassettes can localize in different organelles [36]. The interactions between specific nanoparticles and organelles and the effect triggered by such interactions are presented in Table 2.

A relation between $\mathrm{pH}$ of cell being affected and nanoparticle type entering the cell has also been examined. Nanoparticles were not able to enter the cell in the media at $\mathrm{pH} 7.4$, whilst at $\mathrm{pH}$ between 6.3 and 5.4 were found be enabled in different cellular $\mathrm{pH}$ compartments, such as lysosomes or early endosomes [37] which could be used in drug delivery applications.

\section{Interactions between Nanoparticles and Organic Macromolecules}

Toxicological effects of nanoparticles on the cell structure are caused by their indirect or direct interactions with cellular organic molecules $[5,38]$. The major mechanism underlining NPs-mediated macromolecule toxicity is the disruption of intracellular redox homeostasis which in turn leads to oxidative damage of macromolecules such as lipids, proteins and nucleic acids [38-40]. It is

Table 2. The interactions between specific nanoparticles and organelles and the effect triggered by those interactions.

\begin{tabular}{|c|c|c|c|}
\hline Organelle & Selected nanoparticle & Physiological effect & Ref \\
\hline Cellular membrane & $\begin{array}{l}\text { AuNPs } \\
\text { Polylactide (PLA) coated particles } \\
\mathrm{TiO}_{2}\end{array}$ & $\begin{array}{l}\text {-Disappearance of membrane ruffling } \\
\text {-Increased permeability }\end{array}$ & $\begin{array}{l}{[97,98]} \\
{[99]}\end{array}$ \\
\hline Mitochondria & $\begin{array}{l}\text { PLA coated particles } \\
\mathrm{SiO}_{2} \\
\text { AgNPs }\end{array}$ & $\begin{array}{l}\text {-Swollen mitochondria } \\
\text {-Mitoptosis } \\
\text {-Disruption of the mitochondrial respiratory } \\
\text { chain leading to interruption of ATP synthesis } \\
\text {-Partial fragmentation with limited damage to } \\
\text { actin }\end{array}$ & $\begin{array}{l}{[97]} \\
{[36]} \\
{[100]}\end{array}$ \\
\hline
\end{tabular}

$\begin{array}{ll} & \begin{array}{l}\text { Targeted charge-reversal nanoparticles } \\ \text { (TCRNs) } \\ \text { AuNPs }\end{array}\end{array}$

-Selective migration into the nucleus

Binding with specific proteins or DNA in a nucleus

-Reorganization of nuclear content

-DNA damage and chromosomal aberrations

\section{[98]}

[103]

[100]

\begin{tabular}{|c|c|c|c|}
\hline Nucleolus & $\begin{array}{l}\text { Cadmium telluride (CdTe) nanoparticles } \\
\text { QDs }\end{array}$ & -Interactions with chromatin & [66] \\
\hline Lysosomes & $\mathrm{SiO}_{2}$ & -Cytotoxicity & [36] \\
\hline Peroxisomes & Fullerene $\mathrm{C}_{60}$ & -Changes in acyl-CoA pathways & [104] \\
\hline \multirow[t]{2}{*}{ Endoplasmic reticulum } & $\begin{array}{l}\text { PLA coated particles } \\
\text { poly(lactic-co-glycolic acid) PLGA } \\
\text { nanoparticles }\end{array}$ & $\begin{array}{l}\text {-Widened ER } \\
\text {-Prolonged cross-presentation of the antigen by } \\
\text { the antigen-presenting cells leading to enhanced } \\
\text { activation of cytotoxic T lymphocytes directed } \\
\text { against the tumor cells } \\
\text {-Cytotoxicity }\end{array}$ & $\begin{array}{l}{[97]} \\
{[105]}\end{array}$ \\
\hline & $\mathrm{SiO}_{2}$ & & [36] \\
\hline Cytoskeleton & $\begin{array}{l}\text { AuNPs } \\
\text { AgNPs }\end{array}$ & $\begin{array}{l}\text {-Depolymerisation of } \alpha \text {-tubulin (major } \\
\text { component of microtubules) }\end{array}$ & [101] \\
\hline
\end{tabular}


widely accepted that reactive oxygen species (ROS) play a crucial role in cell metabolism, signaling and homeostasis [41]. Exposure to NPs disturbs the balance between cellular ROS production and detoxification [42]. Moreover, nanoparticle-mediated oxidative stress strictly depends on nanoparticle size, e.g. Mn (40 nm) and Ag (15 $\mathrm{nm}$ ) treatment caused a 10- and 3-fold increase in intracellular ROS production compared to control conditions, respectively [43]. Similar results were obtained after $\mathrm{ZnO}$ [44] and $\mathrm{TiO}_{2}$ [39] exposure to human myeloblastic leukemia cells and bronchial epithelial cells. It was also shown that C-60-induced lipid peroxidation could be prevented by an addition of antioxidant L-ascorbic acid [40]. Peroxidation of lipids can alter the physicochemical properties of membrane lipid bilayers, especially phospholipids, resulting in loss of membrane flexibility, increased ions permeability and cell death [45]. Interactions of NPs with cellular proteins can also lead to abnormal cytophysiology of the cell [46].

Except nanoparticle-mediated changes in protein folding, NPs can trigger different effects on physiological proteins involved in signal transduction and posttranslational modifications $[27,47,48]$. It was observed that super-paramagnetic iron oxide nanoparticles could affect signaling transduction pathways, through an increase in expression of genes responsible for production of tyrosine kinases and several members of the kinase $\mathrm{C}$ family [49]. NPs could also modulate glycation process, e.g. gold-associated inhibition of collagen glycation [46,50] and silver NPs-mediated inhibition of advanced glycation end-products-induced retinal vascular permeability by targeting the Src kinase pathway was reported [51]. Additionally, the effects of NPs on key genes expression were recorded. After silica nanoparticles $(20 \mathrm{~nm})$ treatment, an increase in p53 level and a decrease in Bcl-2 level in hepatoma cells was reported while in hepatic cells cytotoxic effect of $\mathrm{SiO}_{2}$ was slightly observed [52]. Magnetic nanoparticles of $\mathrm{FeO}$ were found to increase the level of Bcl-2 and at the same time decrease the expression of survivin protein which suggested that $\mathrm{FeO}$ can enhance the activity of some drugs such as artesunate used for malaria treatment [53]. Nanoparticle genotoxicity can be also mediated through their interactions with nucleic acids. Nanoparticles can cause DNA damage directly or induce a cascade of evens resulting in DNA damage by acting on the membrane [19]. ZnO nanoparticles were found to induce oxidative stress by glutathione depletion with a concomitant increase in hydroperoxide ions, malondialdehyde levels, reactive oxygen species, and lactate dehydrogenase activity and in turn leading to genotoxicity such as DNA fragmentation [54]. Genotoxic properties of $\mathrm{SiO}_{2}$ and carbon black nanoparticles were also observed after their treatment with human intestinal cell line $[55,56]$. Oxidative stress-mediated depletion in
ATP levels may contribute to limited efficiency of repair processes in the nucleus [57]. Treatment with $\mathrm{TiO}_{2}$ resulted in an increase in mouse eyespots number $(27 \%)$, suggesting that $\mathrm{TiO}_{2}$ increased DNA deletions [10]. Moreover, $\mathrm{TiO}_{2}$ nanoparticles can induce DNA singlestrand breaks, double-strand breaks, oxidative DNA or chromosomal damage in bone marrow cells and maternal exposure to $\mathrm{TiO}_{2}$ NPs during pregnancy results in DNA deletions in offspring [10]. It was also suggested, that gold nanoparticles implemented to the nuclei of cancer cells caused DNA double-strand breaks and induced cytokinesis arrest in cells which in turn resulted in abnormal cell division and cell death [58]. $\mathrm{Fe}_{3} \mathrm{O}_{4}$ was found to cause cell cycle arrest in G2/M phase of rat pheochromocytoma cells [59].

\section{Epigenetic Toxicity of NPs}

As has already been mentioned, some of NPs can penetrate into the nucleus modulating cellular functions and how cell physiology is changed depends on kind of chromatin being affected. NPs-mediated heterochromatin changes cause a dramatic nucleus shrinkage, whilst euchromatin region is only slightly modified. Perturbations in heterochromatin structure may contribute to improper nucleus architecture and its stability. AuNPs were found to modulate heterochromatin connections with lamin proteins and core histones which suggest that NPs could be considered as epigenetic agents [60]. NPs can affect global DNA methylation pattern and/or alter posttranslational modifications of histone proteins. It is known that nanoparticles can induce an increase in ROS production and oxidative DNA damage may affect the ability of methyltransferases to interact with DNA leading to DNA hypomethylation [61]. Moreover, ROS can alter the expression of methylation DNA-regulated genes [62]. On the other hand, it is known that some metal ions, e.g. cadmium ions, can modulate DNA metylotransferase activity [63] suggesting that cadmium can alter DNA methylation pattern. Such an effect strictly depends on duration of cadmium treatment and Cd NPs can be considered as inhibitors or activators of DNA methyltransferase activity. Sites of DNA methylation are controlled by different proteins like MBD (methyl-CpG-binding domain protein) which provide proper enzymatic machinery chromatin silencing [64]. It was observed that with increasing silica nanoparticle doses, the global level of mRNA expression of MBDs gradually decreased. The level of DNA MTase in normal human keratinocytes has changed in the same way which resulted in a decrease of genomic DNA methylation status [65]. CdTe (cadmium telluride) QDs can bind to core histones and the positively charged histones can change the charge and the size of negatively charged QDs which in turn cause an increase in nanoparticle size from 4 to $150 \mathrm{~nm}$ and in the 
NPs charge from $-28.9 \mathrm{mV}$ to $+15 \mathrm{mV}$ and stimulate aggregate formation [66]. Furthermore, cadmium telluride QDs in low concentrations are considered as epigenetic activators of oncogene expression. In QDs-treated human breast cancer cells, two epigenetic changes have been observed: histone 3 hypoacetylation and chromatin decondensation leading to reduction in global gene transcription especially for anti-apoptotic genes. Moreover, an increase in $\mathrm{p} 53$ protein level by its activation via phosphorylation, nucleus and mitochondria translocation and in turn cell death was recorded in QDs-treated cells [67]. All together, it suggests that histone deacetylases (HDAC) could be potentially used as anticancer therapeutics. Cholesterylbutyrate solid lipid nanoparticles releasing butyric acid have been already shown to act as histone deacetylase inhibitors (HDACIs) [68]. Also, K182 HDACI-coated cationic nanoparticles resulted in an increase in gene expression and core histone hyperacetylation [69]. AuNPs were found to decrease histone deacetylase activity by binding to sulfhydryl groups on the surface of histone deacetylase 8 [70]. Additionally, nitric oxide (NO) has been found as an important regulator of epigenetic changes. NO induces S-nitrosylation of histone deacetylase 2 , which leads to chromatin remodeling and significant inhibition of histone deacetylase activity [71]. Nitric oxide-releasing silica NPs have been successfully used for skin and soft tissue infection treatment [72] which suggests that in future, NO-releasing NPs might be commonly used as histone deacetylase inhibitors for epigenetic treatment of cancer.

\section{Conclusion and Future Remarks}

Nanoparticles are ubiquitous in the environment and are widely used in medical science (bioimaging, diagnosis and drug therapy delivery). Moreover, their effectiveness in cancer treatment was repeatedly reported. Due to unique physicochemical properties, they are able to cross many barriers, which is not possible for traditional drugs. Nevertheless, exposure to NPs and their following interactions with organelles and macromolecules can result in negative effects on cells, especially they can induce cytotoxicity and cell death. NPs toxicity can be considered useful for cancer therapy, but simultaneously it seems harmful for non-cancer cells. Recent studies also show that nanoparticles can cause epigenetic and genomic changes which may stimulate cancer progression. "Nanoepigenetics" and "nano-toxicity" are promising and rapidly developing fields in nanoscience and their future achievements might contribute to the development of nanoparticles of limited toxicity and side-effects.

\section{REFERENCES}

[1] P. Pathak and V. K. Katiyar, "Multi-Functional Nanopar- ticles and Their Role in Cancer Drug Delivery: A Review," The A to Z of Nanotechnology, Vol. 3, 2007, pp. $1-17$.

[2] Z. G. Chen, "Small-Molecule Delivery by Nanoparticles for Anticancer Therapy," Trends in Molecular Medicine, Vol. 16, No. 12, 2010, pp. 594-602.

doi:10.1016/j.molmed.2010.08.001

[3] S. K. Murthy, "Nanoparticles in Modern Medicine: State of the Art and Future Challenges," International Journal of Nanomedicine, Vol. 2, No. 2, 2007, pp. 129-141.

[4] K. K. Jain, "Application of Nanobiotechnology in Cancer Therapeutics, in Pharmaceutical Perspectives of Cancer Therapeutics," Springer, New York, 2009, pp. 245-268. doi:10.1007/978-1-4419-0131-6 8

[5] K. Solarska, A. Gajewska, W. Kaczorowski, G. Bartosza and K. Mitura, "Effect of Nanodiamond Powders on the Viability and Production of Reactive Oxygen and Nitrogen Species by Human Endothelial Cells," Diamond and Related Materials, Vol. 21, 2012, pp. 107-113.

[6] M. A. Abdelhalim and B. M. Jarrar, "Histological Alterations in the Liver of Rats Induced by Different Gold Nanoparticle Sizes, Doses and Exposure Duration," Journal of Nanobiotechnology, Vol. 10, 2012, p. 5.

[7] A. Gramowski, J. Flossdorf, K. Bhattacharya, L. Jonas, M. Lantow, Q. Rahman, D. Schiffmann, D. G. Weiss and E. Dopp, "Nanoparticles Induce Changes of the Electrical Activity of Neuronal Networks on Microelectrode Array Neurochips," Environmental Health Perspectives, Vol. 118, No. 10, 2010, pp. 1363-1369. doi:10.1289/ehp.0901661

[8] G. Yan, Y. Huang, Q. Bu, L. Lv, P. Deng, J. Zhou, Y. Wang, Y. Yang, Q. Liu, X. Cen and Y. Zhao, "Zinc Oxide Nanoparticles Cause Nephrotoxicity and Kidney Metabolism Alterations in Rats," Journal of Environmental Science and Health, Part A: Toxic/ Hazardous Substances \& Environmental Engineering, Vol. 47, No. 4, 2012, pp. 577-588.

[9] R. Yoshida, D. Kitamura and S. Maenosono, "Mutagenicity of Water-Soluble ZnO Nanoparticles in Ames Test," Journal of Toxicological Sciences, Vol. 34, No. 1, 2009, pp. 119-122. doi:10.2131/jts.34.119

[10] B. Trouiller, R. Reliene, A. Westbrook, P. Solaimani and R. H. Schiestl, "Titanium Dioxide Nanoparticles Induce DNA Damage and Genetic Instability in Vivo in Mice," Cancer Research, Vol. 69, No. 22, 2009, pp. 8784-8789.

[11] L. Gonzalez, L. C. Thomassen, G. Plas, V. Rabolli, D. Napierska, I. Decordier, M. Roelants, P. H. Hoet, C. E. Kirschhock, J. A. Martens, D. Lison and M. KirschVolders, "Exploring the Aneugenic and Clastogenic Potential in the Nanosize Range: A549 Human Lung Carcinoma Cells and Amorphous Monodisperse Silica Nanoparticles as Models," Nanotoxicology, Vol. 4, 2010, pp. 382-395. doi:10.1158/0008-5472.CAN-09-2496

[12] J. J. Li, D. Hartono, C. N. Ong, B. H. Bay and L. Y. Yung, "Autophagy and Oxidative Stress Associated with Gold Nanoparticles," Biomaterials, Vol. 31, No. 23, 2010, pp. 5996-6003. doi:10.1016/j.biomaterials.2010.04.014

[13] W. Gao, K. Xu, L. Ji and B. Tang, "Effect of Gold Nanoparticles on Glutathione Depletion-Induced Hydrogen 
Peroxide Generation and Apoptosis in HL7702 Cells," Toxicology Letters, Vol. 205, No. 1, 2011, pp. 86-95. doi:10.1016/j.toxlet.2011.05.1018

[14] E. Hodgson, "Modern Toxicology," 3rd Edition, John Wiley \& Sons, Inc., New York, 2004.

[15] S. Arora, J. M. Rajwade and K. M. Paknikar, "Nanotoxicology and in Vitro Studies: The Need of the Hour," Toxicology and Applied Pharmacology, Vol. 258, No. 2, 2012, pp. 151-165. doi:10.1016/j.taap.2011.11.010

[16] G. Oberdorster, E. Oberdorster and J. Oberdorster, "Nanotoxicology: An Emerging Discipline Evolving from Studies of Ultrafine Particles," Environmental Health Perspectives, Vol. 113, No. 7, 2005, pp. 823-839. doi:10.1289/ehp.7339

[17] B. Baroli, "Penetration of Nanoparticles and Nanomaterials in the Skin: Fiction or Reality?" Journal of Pharmaceutical Sciences, Vol. 99, No. 1, 2010, pp. 21-50. doi:10.1002/jps.21817

[18] Z. Chen, H. Meng, G. Xing, C. Chen, Y. Zhao, G. Jia, T. Wang, H. Yuan, C. Ye, F. Zhao, Z. Chai, C. Zhu, X. Fang, B. Ma and L. Wan, "Acute Toxicological Effects of Copper Nanoparticles in Vivo," Toxicology Letters, Vol. 163, No. 2, 2006, pp. 109-120. doi:10.1016/j.toxlet.2005.10.003

[19] M. Simkó, U. Fiedeler, A. Gazsó and M. Nentwich, "The Impact of Nanoparticles on Cellular Functions," NanoTrust-Dossier, No. 007, 2011.

[20] S. A. Mousavi, L. Malerod, T. Berg and R. Kjeken, "Clathrin-Dependent Endocytosis," Biochemical Journal, Vol. 377, No. 1, 2004, pp. 1-16.

[21] H. Pang, P. U. Le and I. R. Nabi, "Ganglioside GM1 Levels Are a Determinant of the Extent of Caveolae/RaftDependent Endocytosis of Cholera Toxin to the Golgi Apparatus," Journal of Cell Science, Vol. 117, No. 8, 2004, pp. 1421-1430.

[22] J. A. Swanson and C. Watts, "Macropinocytosis," Trends in Cell Biology, Vol. 5, No. 11, 1995, pp. 424-428. doi:10.1016/S0962-8924(00)89101-1

[23] A. K. Bouzier-Sore, E. Ribot, V. Bouchaud, S. Miraux, E. Duguet, S. Mornet, G. Clofent-Sanchez, J. M. Franconi and P. Voisin, "Nanoparticle Phagocytosis and Cellular Stress: Involvement in Cellular Imaging and in Gene Therapy against Glioma," NMR in Biomedicine, Vol. 23, No. 1, 2010, pp. 88-96. doi:10.1002/nbm.1434

[24] L. W. Zhang and N. A. Monteiro-Riviere, "Mechanisms of Quantum Dot Nanoparticle Cellular Uptake," Toxicological Sciences, Vol. 110, No. 1, 2009, pp. 138-155. doi:10.1093/toxsci/kfp087

[25] J. S. Chang, K. L. Chang, D. F. Hwang and Z. L. Kong, "In Vitro Cytotoxicitiy of Silica Nanoparticles at High Concentrations Strongly Depends on the Metabolic Activity Type of the Cell Line," Environmental Science \& Technology, Vol. 41, No. 6, 2007, pp. 2064-2068. doi:10.1021/es062347t

[26] R. Hardman, “A Toxicologic Review of Quantum Dots: Toxicity Depends on Physicochemical and Environmental Factors," Environmental Health Perspectives, Vol. 114, No. 2, 2006, pp. 165-172. doi:10.1289/ehp.8284
[27] J. Wang, N. Li, L. Zheng, S. Wang, Y. Wang, X. Zhao, Y. Duan, Y. Cui, M. Zhou, J. Cai, S. Gong, H. Wang and F. Hong, "P38-Nrf-2 Signaling Pathway of Oxidative Stress in Mice Caused by Nanoparticulate $\mathrm{TiO}_{2}$," Biological Trace Element Research, Vol. 140, No. 2, 2011, pp. 186-197. doi:10.1007/s12011-010-8687-0

[28] J. Brooking, S. S. Davis and L. Illum, "Transport of Nanoparticles across the Rat Nasal Mucosa," Journal of Drug Targeting, Vol. 9, No. 4, 2001, pp. 267-279. doi:10.3109/10611860108997935

[29] F. Dechsakulthorn, A. Hayes, S. Bakand, L. Joeng and C. Winder, "In Vitro Cytotoxicity Assessment of Selected Nanoparticles Using Human Skin Fibroblasts," Alternatives to Animal Testing and Experimentation, Vol. 14, Special Issue, 2007, pp. 397-400.

[30] L. Braydich-Stolle, S. Hussain, J. J. Schlager and M. C. Hofmann, "In Vitro Cytotoxicity of Nanoparticles in Mammalian Germline Stem Cells," Toxicological Sciences, Vol. 88, No. 2, 2005, pp. 412-419. doi:10.1093/toxsci/kfi256

[31] Y. Pan, S. Neuss, A. Leifert, M. Fischler, F. Wen, U. Simon, G. Schmid, W. Brandau and W. Jahnen-Dechent, "Size-Dependent Cytotoxicity of Gold Nanoparticles," Small, Vol. 3, No. 11, 2007, pp. 1941-1949. doi:10.1002/smll.200700378

[32] A. Xu, Y. Chai, T. Nohmi and T. K. Hei, "Genotoxic Responses to Titanium Dioxide Nanoparticles and Fullerene in Gpt Delta Transgenic MEF Cells," Particle and Fibre Toxicology, Vol. 6, 2009, p. 3.

[33] J. P. Wise, B. C. Goodale, S. S. Wise, G. A. Craig, A. F. Pongan, R. B. Walter, W. D. Thompson, A. K. Ng, A. M. Aboueissa, H. Mitani, M. J. Spalding and M. D. Mason, "Silver Nanospheres Are Cytotoxic and Genotoxic to Fish Cells," Aquatic Toxicology, Vol. 97, No. 1, 2010, pp. 34-41. doi:10.1016/j.aquatox.2009.11.016

[34] W. H. Suh, K. S. Suslick, G. D. Stucky and Y. H. Suh, "Nanotechnology, Nanotoxicology, and Neuroscience," Progress in Neurobiology, Vol. 87, No. 3, 2009, pp. 133170. doi:10.1016/j.pneurobio.2008.09.009

[35] R. B. Lira, M. B. Cavalcanti, M. A. Seabra, D. C. Silva, A. J. Amaral, B. S. Santos and A. Fontes, "Non-Specific Interactions of $\mathrm{CdTe} / \mathrm{Cds}$ Quantum Dots with Human Blood Mononuclear Cells," Micron, Vol. 43, No. 5, 2012, pp. 621-626. doi:10.1016/j.micron.2011.11.003

[36] M. Al-Rawi, S. Diabaté and C. Weiss, "Uptake and Intracellular Localization of Submicron and Nano-Sized $\mathrm{SiO}_{2}$ Particles in HeLa Cells," Archives of Toxicology, Vol. 85, No. 7, 2011, pp. 813-826. doi:10.1007/s00204-010-0642-5

[37] K. Zhou, Y. Wang, X. Huang, K. Luby-Phelps, B. D. Sumer and J. Gao, "Tunable, Ultrasensitive pH-Responsive Nanoparticles Targeting Specific Endocytic Organelles in Living Cells," Angewandte Chemie International Edition, Vol. 50, No. 27, 2011, pp. 6109-6114. doi:10.1002/anie.201100884

[38] M. R. de Planque, S. Aghdaei, T. Roose and H. Morgan, "Electrophysiological Characterization of Membrane Disruption by Nanoparticles," ACS Nano, Vol. 5, No. 5, 2011, pp. 3599-3606. doi:10.1021/nn103320j 
[39] M. Radu, M. C. Munteanu, S. Petrache, A. I. Serban, D. Dinu, A. Hermenean, C. Sima and A. Dinischiotu, "Depletion of Intracellular Glutathione and Increased Lipid Peroxidation Mediate Cytotoxicity of Hematite Nanoparticles in MRC-5 Cells," Acta Biochimica Polonica, Vol. 57, No. 3, 2010, pp. 355-360.

[40] C. M. Sayes, A. M. Gobin, K. D. Ausman, J. Mendez, J. L. West and V. L. Colvin, "Nano-C60 Cytotoxicity Is Due to Lipid Peroxidation," Biomaterials, Vol. 26, No. 36, 2005, pp. 7587-7595. doi:10.1016/j.biomaterials.2005.05.027

[41] T. P. Devasagayam, J. C. Tilak, K. K. Boloor, K. S. Sane, S. S. Ghaskadbi and R. D. Lele, "Free Radicals and Antioxidants in Human Health: Current Status and Future Prospects," Journal of the Association of Physicians of India, Vol. 52, 2004, pp. 794-804.

[42] Q. Saquib, A. A. Al-Khedhairy, M. A. Siddiqui, F. M. Abou-Tarboush, A. Azam and J. Musarrat, "Titanium Dioxide Nanoparticles Induced Cytotoxicity, Oxidative Stress and DNA Damage in Human Amnion Epithelial (WISH) Cells," Toxicology in Vitro, Vol. 26, No. 2, 2012, pp. 351-361. doi:10.1016/j.tiv.2011.12.011

[43] S. M. Hussain, A. K. Javorina, A. M. Schrand, H. M. Duhart, S. F. Ali and J. J. Schlager, "The Interaction of Manganese Nanoparticles with PC-12 Cells Induces Dopamine Depletion," Toxicological Sciences, Vol. 92, No. 2, 2006, pp. 456-463. doi:10.1093/toxsci/kfl020

[44] M. Premanathan, K. Karthikeyan, K. Jeyasubramanian and G. Manivannan, "Selective Toxicity of $\mathrm{ZnO}$ Nanoparticles toward Gram-Positive Bacteria and Cancer Cells by Apoptosis through Lipid Peroxidation," Nanomedicine, Vol. 7, No. 2, 2011, pp. 184-192. doi:10.1016/j.naNo.2010.10.001

[45] J. P. Kamat, T. P. Devasagayam, K. I. Priyadarsini and H. Mohan, "Reactive Oxygen Species Mediated Membrane Damage Induced by Fullerene Derivatives and Its Possible Biological Implications," Toxicology, Vol. 155, No. 1-3, 2000, pp. 55-61. doi:10.1016/S0300-483X(00)00277-8

[46] L. Fei and S. Perrett, "Effect of Nanoparticles on Protein Folding and Fibrillogenesis," International Journal of Molecular Sciences, Vol. 10, No. 2, 2009, pp. 646-655. doi:10.3390/ijms10020646

[47] G. R. Beck Jr., S. W. Ha, C. E. Camalier, M. Yamaguchi, Y. Li, J. K. Lee and M. N. Weitzmann, "Bioactive SilicaBased Nanoparticles Stimulate Bone-Forming Osteoblasts, Suppress Bone-Resorbing Osteoclasts, and Enhance Bone Mineral Density in Vivo," Nanomedicine, Vol. 8, No. 6, 2011, pp. 793-803.

[48] Y. Cui, H. Liu, M. Zhou, Y. Duan, N. Li, X. Gong, R. Hu, M. Hong and F. Hong, "Signaling Pathway of Inflammatory Responses in the Mouse Liver Caused by $\mathrm{TiO}_{2}$ Nanoparticles," Journal of Biomedical Materials Research A, Vol. 96, No. 1, 2011, pp. 221-229. doi:10.1002/jbm.a.32976

[49] C. C. Berry, S. Charles, S. Wells, M. J. Dalby and A. S. Curtis, "The Influence of Transferrin Stabilised Magnetic Nanoparticles on Human Dermal Fibroblasts in Culture," International Journal of Pharmaceutics, Vol. 269, No. 1,
2004, pp. 211-225. doi:10.1016/j.ijpharm.2003.09.042

[50] J. H. Kim, C. O. Hong, Y. C. Koo, H. D. Choi and K. W. Lee, "Anti-Glycation Effect of Gold Nanoparticles on Collagen," Biological \& Pharmaceutical Bulletin, Vol. 35, No. 2, 2012, pp. 260-264. doi:10.1248/bpb.35.260

[51] S. Sheikpranbabu, K. Kalishwaralal, K. J. Lee, R. Vaidyanathan, S. H. Eom and S. Gurunathan, "The Inhibition of Advanced Glycation End-Products-Induced Retinal Vascular Permeability by Silver Nanoparticles," Biomaterials, Vol. 31, No. 8, 2010, pp. 2260-2271. doi:10.1016/j.biomaterials.2009.11.076

[52] X. Lu, J. Qian, H. Zhou, Q. Gan, W. Tang, J. Lu, Y. Yuan and C. Liu, "In Vitro Cytotoxicity and Induction of Apoptosis by Silica Nanoparticles in Human HepG2 Hepatoma Cells," International Journal of Nanomedicine, Vol. 6, 2011, pp. 1889-1901.

[53] Y. Wang, Y. Han, Y. Yang, J. Yang, X. Guo, J. Zhang, L. Pan, G. Xia and B. Chen, "Effect of Interaction of Magnetic Nanoparticles of $\mathrm{FeO}$ and Artesunate on Apoptosis of K562 Cells," International Journal of Nanomedicine, Vol. 6, 2011, pp. 1185-1192.

[54] A. Kumar, A. K. Pandey, S. S. Singh, R. Shanker and A. Dhawan, "Engineered $\mathrm{ZnO}$ and $\mathrm{TiO}_{2}$ Nanoparticles Induce Oxidative Stress and DNA Damage Leading to Reduced Viability of Escherichia coli," Free Radical Biology \& Medicine, Vol. 51, No. 10, 2011, pp. 1872-1881. doi:10.1016/j.freeradbiomed.2011.08.025

[55] J. A. Sergent, V. Paget and S. Chevillard, "Toxicity and Genotoxicity of Nano-SiO $\mathrm{Si}_{2}$ on Human Epithelial Intestinal HT-29 Cell Line," The Annals of Occupational Hygiene, Vol. 54, No. 5, 2012, pp. 622-630.

[56] J. A. Bourdon, A. T. Saber, N. R. Jacobsen, K. A. Jensen, A. M. Madsen, J. S. Lamson, H. Wallin, P. Moller, S. Loft, C. L. Yauk and U. B. Vogel, "Carbon Black Nanoparticle Instillation Induces Sustained Inflammation and Genotoxicity in Mouse Lung and Liver," Particle and Fibre Toxicology, Vol. 9, 2012, p. 5.

[57] M. Wojewódzka, A. Lankoff, M. Dusińska, G. Brunborg, J. Czerwińska, T. Iwaneńko, T. Stępkowski, I. Szumiel and M. Kruszewski, "Treatment with Silver Nanoparticles Delays Repair of X-Ray Induced DNA Damage in HepG2 Cells," Nukleonika, Vol. 56, No. 1, 2011, pp. 29-33.

[58] B. Kang, M. A. Mackey and M. A. El-Sayed, "Nuclear Targeting of Gold Nanoparticles in Cancer Cells Induces DNA Damage, Causing Cytokinesis Arrest and Apoptosis," Journal of the American Chemical Society, Vol. 132, No. 5, 2010, pp. 1517-1519. doi:10.1021/ja9102698

[59] J. Wu and J. Sun, "Investigation on Mechanism of Growth Arrest Induced by Iron Oxide Nanoparticles in PC12 Cells," Journal of Nanoscience and Nanotechnology, Vol. 11, No. 12, 2011, pp. 11079-11083. doi:10.1166/jnn.2011.3948

[60] A. Mazumder and G. V. Shivashankar, "Gold-Nanoparticle-Assisted Laser Perturbation of Chromatin Assembly Reveals Unusual Aspects of Nuclear Architecture within Living Cells," Biophysical Journal, Vol. 93, No. 6, 2007, pp. 2209-2216. doi:10.1529/biophysj.106.102202

[61] M. Simkó, A. Gazsó, U. Fiedeler and M. Nentwich, 
"Nanoparticles, Free Radicals and Oxidative Stress," NanoTrust-Dossier, No. 012, 2011.

[62] M. Fratelli, L. O. Goodwin, U. A. Orom, S. Lombardi, R. Tonelli, M. Mengozzi and P. Ghezzi, "Gene Expression Profiling Reveals a Signaling Role of Glutathione in Redox Regulation," Proceedings of the National Academy of Sciences of USA, Vol. 102, No. 39, 2005, pp. 1399814003. doi:10.1073/pnas.0504398102

[63] M. Takiguchi, W. E. Achanzar, W. Qu, G. Li and M. P. Waalkes, "Effects of Cadmium on DNA-(Cytosine-5) Methyltransferase Activity and DNA Methylation Status during Cadmium-Induced Cellular Transformation," $E x$ perimental Cell Research, Vol. 286, No. 2, 2003, pp. 355365. doi:10.1016/S0014-4827(03)00062-4

[64] O. Bogdanovic and G. J. Veenstra, "DNA Methylation and Methyl-CpG Binding Proteins: Developmental Requirements and Function," Chromosoma, Vol. 118, No. 5, 2009, pp. 549-565. doi:10.1007/s00412-009-0221-9

[65] C. Gong, G. Tao, L. Yang, J. Liu, Q. Liu and Z. Zhuang, " $\mathrm{SiO}_{2}$ Nanoparticles Induce Global Genomic Hypomethylation in HaCaT Cells," Biochemical and Biophysical Research Communications, Vol. 397, No. 3, 2010, pp. 397400. doi:10.1016/j.bbrc.2010.05.076

[66] J. Conroy, S. J. Byrne, Y. K. Gun'ko, Y. P. Rakovich, J. F. Donegan, A. Davies, D. Kelleher and Y. Volkov, "CdTe Nanoparticles Display Tropism to Core Histones and Histone-Rich Cell Organelles," Small, Vol. 4, No. 11, 2008, pp. 2006-2015. doi:10.1002/smll.200800088

[67] A. O. Choi, S. E. Brown, M. Szyf and D. Maysinger, "Quantum Dot-Induced Epigenetic and Genotoxic Changes in Human Breast Cancer Cells," Journal of Molecular Medicine, Vol. 86, No. 3, 2008, pp. 291-302. doi:10.1007/s00109-007-0274-2

[68] A. Brioschi, G. P. Zara, S. Calderoni, M. R. Gasco and A. Mauro, "Cholesterylbutyrate Solid Lipid Nanoparticles as a Butyric Acid Prodrug," Molecules, Vol. 13, No. 2, 2008, pp. 230-254. doi:10.3390/molecules13020230

[69] Y. Ishii, Y. Hattori, T. Yamada, S. Uesato, Y. Maitani and Y. Nagaoka, "Histone Deacetylase Inhibitor Prodrugs in Nanoparticle Vector Enhanced Gene Expression in Human Cancer Cells," European Journal of Medicinal Chemistry, Vol. 44, No. 11, 2009, pp. 4603-4610. doi:10.1016/i.ejmech.2009.06.036

[70] N. Sule, R. Singh and D. K. Srivastava, "Alternative Modes of Binding of Recombinant Human Histone Deacetylase 8 to Colloidal Gold Nanoparticles," Journal of Biomedical Nanotechnology, Vol. 4, No. 4, 2008, pp. 463-468. doi:10.1166/jbn.2008.011

[71] A. Nott and A. Riccio, "Nitric Oxide-Mediated Epigenetic Mechanisms in Developing Neurons," Cell Cycle, Vol. 8, No. 5, 2009, pp. 725-730. doi:10.4161/cc.8.5.7805

[72] J. H. Shin, S. K. Metzger and M. H. Schoenfisch, "Synthesis of Nitric Oxide-Releasing Silica Nanoparticles," Journal of the American Chemical Society, Vol. 129, No. 15, 2007, pp. 4612-4619. doi:10.1021/ja0674338

[73] V. Sharma, D. Anderson and A. Dhawan, "Zinc Oxide Nanoparticles Induce Oxidative DNA Damage and ROSTriggered Mitochondria Mediated Apoptosis in Human Liver Cells (HepG2)," Apoptosis, Vol. 17, No. 8, 2012, pp. $852-870$.

[74] J. Zhao, L. Xu, T. Zhang, G. Ren and Z. Yang, "Influences of Nanoparticle Zinc Oxide on Acutely Isolated Rat Hippocampal CA3 Pyramidal Neurons," Neurotoxicology, Vol. 30, No. 2, 2009, pp. 220-230. doi:10.1016/j.neuro.2008.12.005

[75] X. Q. Zhang, L. H. Yin, M. Tang and Y. P. Pu, "ZnO, $\mathrm{TiO}_{2}, \mathrm{SiO}_{2}$, and $\mathrm{Al}_{2} \mathrm{O}_{3}$ Nanoparticles-Induced Toxic Effects on Human Fetal Lung Fibroblasts," Biomedical and Environmental Sciences, Vol. 24, No. 6, 2011, pp. 661669.

[76] C. Hanley, A. Thurber, C. Hanna, A. Punnoose, J. Zhang and D. G. Wingett, "The Influences of Cell Type and $\mathrm{ZnO}$ Nanoparticle Size on Immune Cell Cytotoxicity and Cytokine Induction," Nanoscale Research Letters, Vol. 4, No. 12, 2009, pp. 1409-1420. doi:10.1007/s11671-009-9413-8

[77] S. Hackenberg, A. Scherzed, A. Technau, M. Kessler, K. Froelich, C. Ginzkey, C. Koehler, M. Burghartz, R. Hagen and N. Kleinsasser, "Cytotoxic, Genotoxic and ProInflammatory Effects of Zinc Oxide Nanoparticles in Human Nasal Mucosa Cells in Vitro," Toxicology in Vitro, Vol. 25, No. 3, 2011, pp. 657-663. doi:10.1016/j.tiv.2011.01.003

[78] B. L'Azou, J. Jorly, D. On, E. Sellier, F. Moisan, J. Fleury-Feith, J. Cambar, P. Brochard and C. OhayonCourtes, "In Vitro Effects of Nanoparticles on Renal Cells," Particle and Fibre Toxicology, Vol. 5, 2008, p. 22.

[79] E. Belade, L. Armand, L. Martinon, L. Kheuang, J. FleuryFeith, A. Baeza-Squiban, S. Lanone, M. A. Billon-Galland, J. C. Pairon and J. Boczkowski, "A Comparative Transmission Electron Microscopy Study of Titanium Dioxide and Carbon Black Nanoparticles Uptake in Human Lung Epithelial and Fibroblast Cell Lines," Toxicology in Vitro, Vol. 26, No. 1, 2012, pp. 57-66.

doi:10.1016/j.tiv.2011.10.010

[80] J. Catalan, H. Jarventaus, M. Vippola, K. Savolainen and H. Norppa, "Induction of Chromosomal Aberrations by Carbon Nanotubes and Titanium Dioxide Nanoparticles in Human Lymphocytes in Vitro," Nanotoxicology, Vol. 6, 2011, pp. 825-836.

[81] T. Hasezaki, K. Isoda, M. Kondoh, Y. Tsutsumi and K. Yagi, "Hepatotoxicity of Silica Nanoparticles with a Diameter of 100 nm," Pharmazie, Vol. 66, No. 9, 2011, pp. 698-703.

[82] J. Wu, C. Wang, J. Sun and Y. Xue, "Neurotoxicity of Silica Nanoparticles: Brain Localization and Dopaminergic Neurons Damage Pathways," ACS Nano, Vol. 5, No. 6, 2011, pp. 4476-4489. doi:10.1021/nn103530b

[83] A. Panas, C. Marquardt, O. Nalcaci, H. Bockhorn, W. Baumann, H. R. Paur, S. Mulhopt, S. Diabate and C. Weiss, "Screening of Different Metal Oxide Nanoparticles Reveals Selective Toxicity and Inflammatory Potential of Silica Nanoparticles in Lung Epithelial Cells and Macrophages," Nanotoxicology, 2012, in Press. doi:10.3109/17435390.2011.652206

[84] A. Lankoff, M. Arabski, A. Wegierek-Ciuk, M. Kruszewski, H. Lisowska, A. Banasik-Nowak, K. Rozga-Wijas, 
M. Wojewodzka and S. Slomkowski, "Effect of Surface Modification of Silica Nanoparticles on Toxicity and Cellular Uptake by Human Peripheral Blood Lymphocytes in Vitro," Nanotoxicology, 2012, in Press. doi:10.3109/17435390.2011.649796

[85] I. Iavicoli, V. Leso, L. Fontana and A. Bergamaschi, "Toxicological Effects of Titanium Dioxide Nanoparticles: A Review of in Vitro Mammalian Studies," European Review for Medical and Pharmacological Sciences, Vol. 15, No. 5, 2011, pp. 481-508.

[86] I. Pujalte, I. Passagne, B. Brouillaud, M. Treguer, E. Durand, C. Ohayon-Courtes and B. L'Azou, "Cytotoxicity and Oxidative Stress Induced by Different Metallic Nanoparticles on Human Kidney Cells," Particle and Fibre Toxicology, Vol. 8, 2011, p. 10.

[87] G. C. Falck, H. K. Lindberg, S. Suhonen, M. Vippola, E. Vanhala, J. Catalan, K. Savolainen and H. Norppa, "Genotoxic Effects of Nanosized and Fine $\mathrm{TiO}_{2}$," Human \& Experimental Toxicology, Vol. 28, No. 6-7, 2009, pp. 339-352. doi:10.1177/0960327109105163

[88] M. L. Jugan, S. Barillet, A. Simon-Deckers, S. Sauvaigo, T. Douki, N. Herlin and M. Carriere, "Cytotoxic and Genotoxic Impact of $\mathrm{TiO}_{2}$ Nanoparticles on A549 Cells," Journal of Biomedical Nanotechnology, Vol. 7, No. 1, 2011, pp. 22-23. doi:10.1166/jbn.2011.1181

[89] L. P. Sycheva, V. S. Zhurkov, V. V. Iurchenko, N. O. Daugel-Dauge, M. A. Kovalenko, E. K. Krivtsova and A. D. Durnev, "Investigation of Genotoxic and Cytotoxic Effects of Micro- and Nanosized Titanium Dioxide in Six Organs of Mice in Vivo," Mutation Research, Vol. 726, No. 1, 2011, pp. 8-14. doi:10.1016/j.mrgentox.2011.07.010

[90] M. A. Abdelhalim and B. M. Jarrar, "Gold Nanoparticles Administration Induced Prominent Inflammatory, Central Vein Intima Disruption, Fatty Change and Kupffer Cells Hyperplasia," Lipids in Health and Disease, Vol. 10, 2011, p. 133.

[91] M. A. Abdelhalim, "Gold Nanoparticles Administration Induces Disarray of Heart Muscle, Hemorrhagic, Chronic Inflammatory Cells Infiltrated by Small Lymphocytes, Cytoplasmic Vacuolization and Congested and Dilated Blood Vessels," Lipids in Health and Disease, Vol. 10, 2011, p. 233.

[92] J. H. Sung, J. H. Ji, J. D. Park, M. Y. Song, K. S. Song, H. R. Ryu, J. U. Yoon, K. S. Jeon, J. Jeong, B. S. Han, Y. H. Chung, H. K. Chang, J. H. Lee, D. W. Kim, B. J. Kelman and I. J. Yu, "Subchronic Inhalation Toxicity of Gold Nanoparticles," Particle and Fibre Toxicology, Vol. 8, 2011, p. 16.

[93] J. J. Li, S. L. Lo, C. T. Ng, R. L. Gurung, D. Hartono, M. P. Hande, C. N. Ong, B. H. Bay and L. Y. Yung, "Genomic Instability of Gold Nanoparticle Treated Human Lung Fibroblast Cells," Biomaterials, Vol. 32, No. 23, 2011, pp. 5515-5523. doi:10.1016/j.biomaterials.2011.04.023

[94] Z. Zhang, R. D. Ross and R. K. Roeder, "Preparation of Functionalized Gold Nanoparticles as a Targeted X-Ray Contrast Agent for Damaged Bone Tissue," Nanoscale, Vol. 2, No. 4, 2010, pp. 582-586. doi:10.1039/b9nr00317g

[95] W. K. Khalil, E. Girgis, A. N. Emam, M. B. Mohamed and K. V. Rao, "Genotoxicity Evaluation of Nanomaterials: DNA Damage, Micronuclei, and 8-Hydroxy-2-deoxyguanosine Induced by Magnetic Doped CdSe Quantum Dots in Male Mice," Chemical Research in Toxicology, Vol. 24, No. 5, 2011, pp. 640-650. doi: $10.1021 / \mathrm{tx} 2000015$

[96] A. Dhawan, J. S. Taurozzi, A. K. Pandey, W. Shan, S. M. Miller, S. A. Hashsham and V. V. Tarabara, "Stable Colloidal Dispersions of C60 Fullerenes in Water: Evidence for Genotoxicity," Environmental Science \& Technology, Vol. 40, No. 23, 2006, pp. 7394-7401. doi:10.1021/es0609708

[97] S. M. Moghimi, A. C. Hunter and J. C. Murray, "LongCirculating and Target-Specific Nanoparticles: Theory to Practice," Pharmacological Reviews, Vol. 53, No. 2, 2001, pp. 283-318.

[98] K. Sanderson, "Gold Nanoparticles Revealed," Nature, 2007, p. 178. doi:10.1038/news.2007.178

[99] P. Thevenot, J. Cho, D. Wavhal, R. B. Timmons and L. Tang, "Surface Chemistry Influences Cancer Killing Effect of $\mathrm{TiO}_{2}$ Nanoparticles," Nanomedicine, Vol. 4, No. 3, 2008, pp. 226-236. doi:10.1016/j.nano.2008.04.001

[100] P. V. AshaRani, G. L. K. Mun, M. P. Hande and S. Valiyaveettil, "Cytotoxicity and Genotoxicity of Silver Nanoparticles in Human Cells," ACS Nano, Vol. 3, No. 2, 2009, pp. 279-290.

[101] V. K. Raghunathan, S. Hawkins, C. P. Case, S. Mann, S. Davis and J. Lane, "Factors That May Affect the Nanotoxicology of Hard Materials for Surgical Applications, Characterising the Potential. Risks Posed by Engineered Nanoparticles," A Second UK Government Research Report Programme project (079/0006), DEFRA 2011. http://www.defra.gov.uk

[102] M. Dance, "The Use of Targeted Charge-Reversal Nanoparticles (TCRNS) to Investigate Nuclear Delivery of Fluorescent Agents to Cancer Cells: Implications for Novel Prostate and Breast Cancer Therapy," Virginia Commonwealth University, Richmond, 2011. http://www.hdl.handle.net/10156/13587

[103] C. T. Ng, S. T. Dheen, W. C. Yip, C. N. Ong, B. H. Bay and L. Y. L. Yung, "The Induction of Epigenetic Regulation of PROS1 Gene in Lung Fibroblasts by Gold Nanoparticles and Implications for Potential Lung Injury," Biomaterials, Vol. 32, No. 30, 2011, pp. 7609-7615. doi:10.1016/j.biomaterials.2011.06.038

[104] E. Oberdörstera, S. Zhuc, T. M. Blickleyb, P. McClellanGreend and M. L. Haasche, "Ecotoxicology of CarbonBased Engineered Nanoparticles: Effects of Fullerene (C60) on Aquatic Organisms," Carbon, Vol. 44, No. 6, 2006, pp. 1112-1120. doi:10.1016/j.carbon.2005.11.008

[105] H. Sneh-Edri, D. Likhtenshtein and D. Stepensky, "Intracellular Targeting of PLGA Nanoparticles Encapsulating Antigenic Peptide to the Endoplasmic Reticulum of Dendritic Cells and Its Effect on Antigen Cross-Presentation in Vitro," Molecular Pharmaceutics, Vol. 8, No. 4, 2011, pp. 1266-1275. doi:10.1021/mp200198c

[106] X. L. Song, B. Li, K. Xu, J. Liu, W. Ju, J. Wang, X. D. 
Liu, J. Li and Y. F. Qi, "Cytotoxicity of Water-Soluble mPEG-SH-Coated Silver Nanoparticles in HL-7702 Cells," Cell Biology and Toxicology, Vol. 28, No. 4, 2012, pp. 225-237. doi:10.1007/s10565-012-9218-x

[107] T. H. Kim, M. Kim, H. S. Park, U. S. Shin, M. S. Gong and H. W. Kim, "Size-Dependent Cellular Toxicity of Silver Nanoparticles," Journal of Biomedical Materials Research Part A, Vol. 100, No. 4, 2012, pp. 1033-1043. doi:10.1002/jbm.a.34053

[108] A. K. Patlollal, D. Hackett and P. Tchounwou, "Genotoxicity Study of Silver Nanoparticles in Bone Marrow Cells of Sprague-Dawley Rats," 7th International Symposium on Recent Advances in Environmental Health Research,
Jackson, 12-15 September 2010.

http://ehr.cset.jsums.edu/7cd/OralPdf/Oral\%2011.pdf

[109] M. Mahmoudi, S. Laurent, M. A. Shokrgozar and M. Hosseinkhani, "Toxicity Evaluations of Superparamagnetic Iron Oxide Nanoparticles: Cell 'Vision' versus Physicochemical Properties of Nanoparticles," ACS Nano, Vol. 5, No. 9, 2011, pp. 7263-7276. doi: $10.1021 / \mathrm{nn} 2021088$

[110] A. K. Gupta and M. Gupta, "Cytotoxicity Suppression and Cellular Uptake Enhancement of Surface Modified Magnetic Nanoparticles," Biomaterials, Vol. 26, No. 13, 2005, pp. 1565-1573. doi:10.1016/j.biomaterials.2004.05.022 